\title{
ENVIRONMENTAL MANAGEMENT IN SMEs: ORGANIZATIONAL AND SECTORAL DETERMINANTS IN THE CONTEXT OF AN OUTERMOST EUROPEAN REGION
}

\author{
Yaiza ARMAS-CRUZ' ${ }^{1}$, Esperanza GIL-SOTO², \\ Juan Ramón OREJA-RODRÍGUEZ ${ }^{3}$ \\ Department of Business Administration and Economic History, Universidad de La Laguna, \\ Apartado 456, La Laguna, 38200 Spain \\ E-mails: ${ }^{1}$ yarmas@ull.edu.es (corresponding author); ${ }^{2}$ egilsoto@ull.edu.es; 3joreja@ull.es
}

Received 29 March 2017; accepted 27 August 2017

\begin{abstract}
This paper evaluates the environmental behavior of SMEs in the Canary Islands (Spain), one of the Outermost European Regions. The islands' fragile socioeconomic systems and scarce resources noticeably condition the competitiveness of their firms. An empirical analysis ranks environmental protection practices in SMEs and identifies differences on the basis of size and business sector. In addition, groups of firms with different environmental behavior are identified to facilitate the design of environmental policies, improve effectiveness in decision making and the more efficient use of resources. From a theoretical perspective, this paper contributes to the gap identified by the precursors of the Natural Resource-Based View of the firm by analyzing specific resource combinations that each firm can use to improve its environmental performance and achieve competitive advantages. The firms best positioned to develop the dynamic capabilities needed are identified not only considering the physical environment, but also the socio-economic one and key intangible resources are measured that shape firms' environmental strategy.
\end{abstract}

Keywords: environmental management, small and medium-sized enterprises, OERs, sector, Resource-Based Theory, Rasch Measurement Theory.

JEL Classification: M14, M21, Q55.

\section{Introduction}

Island territories face considerable challenges to achieve sustainable development and firms play a key role in this development. The predominance of small and medium-sized enterprises (SMEs) in Europe, particularly in Outermost European Regions (OERs), justifies the interest in analyzing the determinants of SMEs' competitiveness in these regions, especially as islands are often conditioned by fragile socioeconomic systems and a globalized context that exacerbates environmental problems (Benito-Hernández et al. 2016). Therefore, SMEs of OERs must achieve compatibility between competitiveness and sustainability to guarantee their survival. 
The insular condition of the majority of the OERs as well as demographic pressure and the steady growth of tourism have had a great impact on the natural environment and increase the complexity and cost of sustainable development in these regions (Calado et al. 2014; Gil et al. 2012). Furthermore, from a scientific and social science perspective, "islands present themselves as self-contained units to examine sustainability" (Baldacchino 2007: 14). Moreover, the specific features of insular settings make it difficult to generalize conclusions from their study. This is why island studies are a growing field of research that should be more fully explored (Pugh 2016), considering distinct cultural geographies and islands' varying performances (Stratford et al. 2011). Indeed, their analysis should not be considered as a pursuit by islands/islanders, or with them, not even for them, but of them (Baldacchino 2008; Stratford et al. 2011).

In the literature, there is a gap concerning whether SMEs are ideally placed to gain competitive advantages through environmental management -EM- (Torugsa et al. 2012; Aragón, Iturrioz 2016; Benito-Hernández et al. 2016). In this respect, Resource-Based Theory (RBT) (Barney 1991, 2001a, 2001b; Barney et al. 2001) is one of the most widely-accepted theoretical approaches to understand how corporate social and environmental responsibility (CSR) can contribute to create competitive advantage (Aguinis, Glavas 2012; Frynas, Stephen 2015). According to RBT, the limitations that SMEs have to access strategic resources could be offset by their ability to develop specific 'capabilities' (e.g., greater flexibility, innovation, proximity, etc.) and to design proactive social and environmental strategies to create value and differentiate themselves. However, RBT has been under utilized in research into CSR in SMEs, compared to other approaches such as Stakeholder Theory that focuses on external drivers rather than internal ones (Herrera-Madueño et al. 2016; Frynas, Stephen 2015; Frynas, Yamahaki 2016; Rodríguez-Fernández 2016).

Another aspect scarcely explored is the heterogeneity of environmental behavior among small and medium-sized enterprises and their varied CSR practices. So far, most studies have focused only on the implementation of formal and certifiable processes of EM, with the industrial sector being the most studied, as it is subject to greater regulatory control.

Bearing in mind these research challenges, this paper contributes to both theoretical and empirical perspectives. Firstly, it addresses the gap in the literature pertaining to the utilization of RBT, and its particular application to natural resources: the Natural ResourceBased View of the firm (NRBV) (Hart 1995), focusing on SMEs' internal dynamics to develop value-creating responsible strategies. This paper also provides advances in the measurement of unobservable variables (Godfrey, Hill 1995) that are the theoretical core of the RBT (Barney et al. 2001, 2011). Additionally, it contributes by proposing a matrix with different profiles of EM in SMEs. This permits the identification of the best positioned firms to develop the dynamic capabilities needed to bring clean technologies to market. Moreover, the heterogeneity of EM is explored among small and mediumsized firms, according to gaps identified in literature (Barney et al. 2011; Hart, Dowell 2011; Brammer et al. 2012). There is also a comparison between business sectors, given that significant differences exist in the nature of EM depending on the greater or lesser 
orientation to the customer (Armas-Cruz 2011). This is especially important in small isolated islands, where industry is less important compared to sectors such as services. This comparison is useful as the composition of the business fabric of the Canary Islands (Spain) is representative of the determining features of an OER.

The paper is structured as follows. First, a theoretical framework reviews the basis of strategic management of the environmental factor, with special reference to SMEs determinants and sectoral particularities. This supports the proposal of a measurement scale that will be applied in the context of the Canary Islands. Second, an empirical study examines the interaction of both organizational aspects and specific EM ones using an objective measurement instrument. Finally, the paper presents the discussion of the results and conclusions.

\section{Theoretical foundations of environmental management}

Transaction Cost Theory (Coase 1937; Williamson 1985), Agency Theory (Jensen, Meckling 1976) and Resource-Based Theory (RBT) (Barney 1991) reveal the central role of state-unobservable constructs in strategic management literature (Godfrey, Hill 1995: 520). This paper focuses on RBT's internal capacities, particularly organizational ones, such as EM, and the relevance achieved by this theory in the 1990s as an alternative to other environmental models (Porter 1980) to explain the origin of firms' competitive advantages.

RBT (Barney 1991, 2001a, 2001b; Barney et al. 2001) affirms that the characteristics that enable a resource or capability to generate a sustainable competitive advantage are: heterogeneity, imperfect mobility, and ex-ante and ex-post limits to competition. Several authors have explained the presence of these characteristics in the environmental context (McWilliams, Siegel 2011; Wong et al. 2015: 42).

First, there is heterogeneity in the environmental behavior of firms, as they use different production factors (natural and unnatural) and generate different emissions. This heterogeneity is also due to the development of valuable organizational capacities, which is a dynamic and adaptive process, based on skills as well as processes and procedures (Teece 2007). As a result of above, there are ex-post competition limits of environmental protection activities that make it difficult for competitors to imitate these activities (McWilliams, Siegel 2011; Wong et al. 2015).

Second, there is imperfect substitutability, since for environmentally-conscious customers; there are often no substitutes for the products or for the environmentally responsible organizations they wish to purchase from. In addition, there are barriers that prevent firms from imitating identically the environmental protection system of others due to the socially complex and tacit character of environmental protection, which is based on the learning and continuous improvement of firms' employees and personnel (Hart 1995; Wong et al. 2015).

These aspects are known as first mover advantages and are associated with a better environmental reputation and greater efficiency in the use of resources. Certain addi- 
tional assets (technical, interpretative structures and a network of efficient communication) are also required to successfully incorporate environmental protection activities into firms (Christmann 2000; López-Gamero et al. 2009; Porter, Van der Linde 1995). However, with respect to firms' green reputations, Jong et al. (2014) point out that firms must prove that they are consistently sustainable in the long term before obtaining any market-related benefits through increased customer base.

Third, a firm's environmental management has imperfect mobility, since these practices are specially designed for its particular activities and needs (Gupta, Sharma 1996; Wong et al. 2015). Finally, there are ex-ante limits to competition explained in part by the above first mover advantages in incorporating environmental technologies, as well as the need for a learning curve in incorporating environmental technologies and improving environmental performance (Christmann 2000; Porter, Van der Linde 1995).

Thus, from the RBT emerges the Natural Resource-Based View of the firm (NRBV0 (Hart 1995), which links this approach to environmental protection. NRBV proposes that the ability to integrate the natural environment into the strategic planning process and offers a firm the chance to develop an organizational capability that is valuable, potentially rare, and difficult to imitate. This approach includes the constraints and challenges that the natural environment places on a firm, and "how resources and capabilities rooted in the firm's interaction with its natural environment can lead to competitive advantages" (Barney et al. 2011: 1310).

Subsequent studies have reaffirmed the utility of NRBV to analyze the integration of the environment variable in a firm's strategic planning to generate a sustainable competitive advantage (Armas-Cruz 2011; Herrera-Madueño et al. 2016; Larrán-Jorge et al. 2015; López-Gamero et al. 2016; Martín-de Castro et al. 2016; Mohd et al. 2015; Tomomi 2010). This is possible by making use of three interconnected strategies: pollution prevention, product stewardship and sustainable development to achieve superior performance by reducing costs, preempting competitors and enhancing future position (Mohd et al. 2015: 413; Wong et al. 2015: 35, 46). Additionally, it is necessary to consider the moderating effect that the organizational context has on the deployment of a firm's capability to integrate stakeholders' perspectives in developing its environmental strategy (Rueda-Manzanares et al. 2008; Verbeke et al. 2006).

Moreover, Verbeke et al. (2006) and Martín-de Castro et al. (2016) indicate that, to obtain superior performance, not only is the design of the environmental strategy important but also an adequate investment in certain resource domains (employees' green skills, formal environmental systems, etc.) that increases the possibility of developing valuable capabilities by improved learning and stakeholder integration.

Currently, both the RBT and the NRBV continue to underpin advances in research, as indicated by their precursors (Barney et al. 2011; Hart, Dowell 2011). They identify a number of areas for further inquiry that our research aims to contribute to. On the one hand, this paper analyses the strategic capabilities of "pollution prevention" and "clean technology" identified by Hart and Dowell (2011). On the other, it investigates how firms combine their resources to improve their environmental performance, and 
which firms are best positioned to develop the dynamic capabilities needed to bring clean technologies to market. Also, according to these authors, and in our paper, both the theoretical approach and the measurement instrument must conceptualize the environment from a broad perspective, taking into account not only the link between a firm and the physical environment, but also the firm's relationship with stakeholders and the socio-economic environment in which it operates.

Barney et al. (2011) proposed that one of key issues in RBT today is the measurement of resources because many of them are intangible, as stated by Godfrey and Hill (1995). They find that "intangible resource assessment and construct validation are often performed as mechanical, empirical, and uni-disciplinary and uni-level processes rather than as a conceptual, multidisciplinary, multilevel, and theoretical one" (Barney et al. 2011: 1311). Furthermore, they consider that applications of RBT should evolve towards a combination of quantitative and qualitative approaches. In this sense, our paper contributes by applying methods and measurement models of latent variables linked to the Modern Test Theory. These contributions are in line with other developments already present in the literature on Strategic Management such as those presented by OrejaRodríguez and Armas-Cruz (2012) within the field of Rasch Measurement Theory and those of Carroll et al. (2016) in the context of the Item Response Theory.

\section{Environmental management in SMEs}

The economic relevance of SMEs, especially in Europe (99\% of all businesses in 2016), suggests that their environmental impacts warrant greater attention. However, empirical research into EM in SMEs is much sparser than for large corporations (Gadenne et al. 2009; Jamali et al. 2009). Several reasons for this apparently low level of engagement with environmental issues among SMEs have been advanced in previous research.

According to Brammer et al. (2012: 425), "small businesses have different behavioral characteristics compared to larger firms regarding EM. In general, SMEs have relatively informal organizational structures and are often managed by owners". As a result, personal attitudes, leadership skills and environmental information available to owners can greatly affect socially responsible behavior (Aragón, Iturrioz 2016; Herrera-Madueño et al. 2015; Moore et al. 2009). On the other hand, SMEs have greater levels of flexibility to respond to the business environment and competitors' actions (Aragón-Correa et al. 2008). Besides, for SMEs, it is essential to establish cooperative relationships with key stakeholders, which allow them access to external funding and business opportunities to improve their social-environmental performance (Aragón, Iturrioz 2016; Benito-Hernández et al. 2016).

In general terms, SME management does not develop a strategic approach to EM towards achieving competitive advantages (Graafland et al. 2003; Jamali et al. 2009; Revell, Blackburn 2007). The majority limit themselves to compliance with legal requirements and those of their principal stakeholders, bearing the costs involved (BenitoHernández et al. 2016; Lepoutre, Heene 2006; Udayasankar 2008). The low formalization of EM of SMEs is seen even more in economically vulnerable contexts (Jamali 
et al. 2009) like OERs. So, the likelihood of SMEs taking on the increasingly complex challenges of sustainability is conditioned by their ability to integrate it properly into their policies (Blundel et al. 2013).

However, Brammer et al. (2012) and Nybakk and Panwar (2015) consider that SMEs are not a homogeneous group with respect to socio-environmental management. So, it is of interest to identify specific features within this segment, for example, differences between small and medium-sized enterprises, which are the object of analysis in our study.

In addition, in the literature, there has been insufficient emphasis placed on the specific competences that firms should develop to facilitate the adoption of environmental protection practices, especially collaboration with other firms and product innovation (Hofmann et al. 2012). In short, it is necessary to study the environmental performance of SMEs in particularly complex contexts of competition, such as those of OERs. These kinds of contexts can influence the organizational and management features that explain SMEs' EM.

Finally, with respect to sectoral differences in EM, Banerjee (2002) identifies sectoral features that moderate the relationship between corporate environmentalism and business performance, such us the degree of environmental regulation, the level of environmental impact a sector produces and the level of concern society has regarding a specific sector's environmental behavior. Particularly, Husillos and Álvarez-Gil (2008) find that sectors with a direct environmental impact display greater transparency when declaring their environmental practices. So, our study aims to widen this perspective of the disclosure of environmental information and to analyze whether sectoral differences exist at the level of development of EM.

\section{Methodology}

This study proposes "environmental management" (EM) as its central construct of analysis (Armas-Cruz 2011; Oreja-Rodríguez, Armas-Cruz 2012). This construct is updated in terms of its theoretical delimitation and use as a measurement instrument applicable to the specific context and internal peculiarities of SMEs. Table 1 compiles the theoretical background that supports the construct, dimensions and proposed items.

According to Bos-Brouwers (2010) and Gadenne et al. (2009), the analysis of EM, and more specifically in the context of SMEs, must examine the broad complexity and diversity of practices that reflect the environmental concerns of a firm, covering from more strategic and planning questions to more operative and commercial tasks. Thus, this paper applies this transverse vision of EM to gather better the diversity depending on a firm's size and sector.

In addition, the paper analyses other aspects of management highly significant to complete the environmental profile of SMEs (Aragón-Correa et al. 2008; Fassin 2008; Hofmann et al. 2012; Lawrence et al. 2006; López-Gamero et al. 2009), such as: "business resources devoted to environmental protection" and "situation of a firm with regard to accreditation/certification of its EM". 
Accordingly, the following specific objectives are proposed:

1. To validate the EM construct (Armas-Cruz 2011; Oreja-Rodríguez, Armas-Cruz 2012) when it is applied to SMEs in an insular setting. A measurement instrument is proposed that is capable of correctly evaluating the environmental behavior of SMEs in the context of specific geographical, environmental and socioeconomic characteristics, like the Canary Islands.

2. To analyze the hierarchization of environmental practices in SMEs.

3. To obtain a typology of Canary Island SMEs, as an example of an OER context, as a result of their level of EM and other aspects of management (resources employed, motivation and obstacles to EM) and to determine whether differences exist in the environmental behavior of SMEs according to their size and sector.

\subsection{Measurement instrument}

A questionnaire has been designed to measure the construct EM in SMEs' which includes a block of 12 questions that lists the (practical) most representative actions of EM in Canary Islands SMEs (Table 1). The measuring range is ordered polytomous categories.

Table 1. EM in SMEs

\begin{tabular}{ll}
\hline $\begin{array}{l}\text { A) Integration of environment in organization's strategic } \\
\text { management and planning process }\end{array}$ & Theoretical background \\
\hline EM.1 Implementation of EM System & Aragón-Correa (1998); \\
\hline EM.2 Implementation of Code of Good Practices & Armas-Cruz (2011); \\
Benito-Hernández et al. \\
EM.3 Environmental criteria in investments/purchases & $(2016) ;$ Christmann (2000); \\
\hline B) Prevention (of environmental impact) & Curkovic and Sroufe \\
\hline EM.4 Prevention of environmental accidents & (2016); Deng et al. (1992); \\
\hline EM.5 Collaboration in promotion of culture and socioeconomic & González-Benito, J. and \\
development of area & Hart (1995); Hart and Ahuja \\
\hline C) Control (of environmental impact) & (1996); Henriques and \\
\hline EM.6 Saving natural resources and preserving their quality & Sadorsky (1996); Hunt and \\
\hline EM.7 Reduction of waste and use of polluting and/or dangerous & Auster (1990); Judge and \\
substances & Douglas (1998); Kirk (1995, \\
1998); Klassen and Whybark \\
(1999); Kleiner (1991);
\end{tabular}

Scale $: 1$ = Not applied; 2 = Under development; 3 = Applied; 4 = Don't know/No answer. 
Additionally, to evaluate the business resources employed, the questionnaire includes two relative questions, firstly regarding the volume of economic, human and technical resources employed and, secondly, concerning the volume of investment in the field of environmental protection.

\subsection{Study population and sample}

The study population comprises 6,824 firms established in Canary Islands, with a number of employees between 10 and 250 (updated from $\mathrm{SABI}^{1}$ ). Simple, stratified random sampling was applied with mixed proportionality, taking as strata the codes of the National Classification of Economic Activities (CNAE). Data gathering was performed via a telephone survey to the manager of the firms. The methodological characteristics of the empirical study are summarized in Table 2.

Table 2. Specifications of the empirical study

\begin{tabular}{ll}
\hline Universe & Small and medium-sized enterprises (10-250 employees) \\
\hline Population & 6,824 SMEs from Canary Islands \\
\hline Final size of the sample & 459 \\
\hline Sample error (level of confidence) & $+/-4.68 \%(95 \% ; \mathrm{p}=0.5)$ \\
\hline Date of fieldwork & First quarter of 2015 \\
\hline Treatment of the information & SPSS 21 and Winsteps, 3.80 .1 \\
\hline
\end{tabular}

\subsection{Data analysis}

459 questionnaires were obtained, completed by directors of SMEs belonging to the following sectors: industry (33\%), construction (21\%), hospitality $(10 \%)$, transport $(9 \%)$ and others -including distribution and retail- (27\%). The sample comprises $71 \%$ of small firms (10-49 employees) and 29\% of medium-sized enterprises (50-250 employees).

To analyze the data, Rasch Measurement Theory (RMT) (Rasch 1960; Wang 2010) was used. RMT enables improved measurement of Strategic Management, complying with the requirements established by Barney et al. $(2001,2011)$, as well as with the outstanding methodological elements proposed by Godfrey and Hill (1995) and Boyd et al. (2005). RMT applies demanding requirements in the process of questionnaire optimization and the subsequent analysis of reliability and overall validity of the measurements obtained (Sarstedt et al. 2015). Secondly, a cluster analysis identifies homogenous groups in the sample.

\footnotetext{
${ }^{1}$ System of Analysis of Iberian Balance Sheets (SABI): Financial database of Spanish and Portuguese firms, obtained from official sources. Supplier: INFORMA D\&B S.A (https://www.einforma.com/ sabi).
} 


\section{Results}

\subsection{Overall reliability of separation and validity of measures}

As a prior step, an analysis was made of the data to eliminate the responses which may distort the measurement of EM in SMEs in the sample. Following this debugging of the questionnaire, a sample of 412 SMEs was obtained with which the parameters were estimated, using the maximum likelihood method. The results are summarized in Table 3.

Table 3. Statistics of EM factors

\begin{tabular}{lcccccccc} 
& \multicolumn{2}{c}{ Measure } & \multicolumn{2}{c}{ INFIT MNSQ } & \multicolumn{2}{c}{ OUTFIT MNSQ } & \multirow{2}{*}{ Separation (Model) } & Reliability \\
\cline { 2 - 7 } & Mean & S.D. & Mean & S.D. & Mean & S.D. & & \\
\hline SMEs & 0.69 & 1.49 & 1.01 & 0.34 & 0.91 & 0.52 & 1.53 & 0.70 \\
\hline EM items & 0 & 1.37 & 1.00 & 0.13 & 0.91 & 0.25 & 9.15 & 0.99 \\
\hline
\end{tabular}

The overall reliability of separation and adjustment (validity) of the measures are confirmed. The validity can be seen in the analysis of the MNSQ infit and outfit values, which are situated within the accepted interval for the construction of measures, between 0.50 and 1.50 (Linacre 2002). Furthermore, the reliability of the measures obtained from the SMEs and the items reach values equal to or above 0.70 . The variance explained indicates that the measures explain $40.5 \%$ of the variance of the data with an Eigenvalue in the first test equal to 2 , which recognizes the unidimensionality of the scale.

These results demonstrate that the first objective has been achieved, confirming that the measures of the items of the construct 'EM of SMEs in a OERs are globally reliable and valid.

\subsection{Hierarchization of the environmental protection practices}

The second objective consists of obtaining a hierarchical list of the environmental practices of Canary Island SMEs, for which a joint positioning analysis of the items is performed using RMT (Engelhard 2013). The results confirm that the two strategies with the lowest measurements, that is to say the most frequent, are "Adequate management of waste and dangerous substances" (EM9) and "Training and motivation of staff in environmental objectives" (EM11). In turn, the environmental protection policies with the highest measurements, that is to say, those which are applied to a lesser degree by Canary Island SMEs, are "Control of regulations" (EM8) and "Implementation of EM System" (EM1) (see Rasch measure in Table 4).

Next, a frequency analysis determines what practices are more or less important, depending on the size of the firm and the sector. The result by sector via the frequency tables (Table 4) confirms that obtained previously using RMT. That is to say, EM9 is applied to the greatest extent (over 91\%) in all sectors except transport, in which EM11 is the most frequent. By contrast, the "implementation of EM system" (EM1) is the least widespread in all sectors (under 50\%), except in that of "transport and others", in which the least frequent practices are "reduction of waste and use of polluting and/or dangerous substances" (EM7) and "control of regulations" (EM8), respectively. 
Table 4. Environmental practices applied by sector and size

\begin{tabular}{lccccccccc}
\hline & $\begin{array}{c}\text { Rasch } \\
\text { measure }\end{array}$ & Industrial & $\begin{array}{c}\text { Construc- } \\
\text { tion }\end{array}$ & $\begin{array}{c}\text { Hospi- } \\
\text { tality }\end{array}$ & Transport & Others & Small & Medium & Total \\
\hline EM1 & 2.64 & $\mathbf{4 6 . 7}$ & $\mathbf{4 4 . 7}$ & $\mathbf{5 0 . 0}$ & 55.3 & 44.6 & $\mathbf{4 2 . 0}$ & 59.8 & $\mathbf{4 6 . 8}$ \\
EM2 & 0.14 & 67.4 & 81.2 & 78.6 & 68.4 & 78.6 & 72.0 & 81.3 & 74.5 \\
EM3 & 0.09 & 68.1 & 74.1 & 78.6 & 65.8 & 75.0 & 69.7 & 78.6 & 72.1 \\
EM4 & -0.20 & 78.5 & 77.6 & 73.8 & 76.3 & 75.9 & 74.0 & 84.8 & 76.9 \\
EM5 & -0.28 & 78.5 & 81.2 & 83.3 & 68.4 & 75.9 & 76.0 & 83.0 & 77.9 \\
EM6 & -0.58 & 83.0 & 89.4 & 92.9 & 84.2 & 75.9 & 81.7 & 88.4 & 83.5 \\
EM7 & 1.81 & 56.3 & 58.8 & 59.5 & $\mathbf{4 4 . 7}$ & 47.3 & 46.3 & 73.2 & 53.6 \\
EM8 & 1.94 & 51.9 & 48.2 & 52.4 & 47.4 & $\mathbf{3 8 . 4}$ & 42.7 & $\mathbf{5 8 . 9}$ & 47.1 \\
EM9 & -1.94 & $\mathbf{9 5 . 6}$ & $\mathbf{9 1 . 8}$ & $\mathbf{9 7 . 6}$ & 84.2 & $\mathbf{9 1 . 1}$ & $\mathbf{9 1 . 7}$ & $\mathbf{9 5 . 5}$ & $\mathbf{9 2 . 7}$ \\
EM10 & -1.15 & 88.9 & 80.0 & 95.2 & 86.8 & 78.6 & 82.3 & 91.1 & 84.7 \\
EM11 & -1.37 & 91.1 & 78.8 & 95.2 & $\mathbf{9 2 . 1}$ & 81.3 & 84.7 & 91.1 & 86.4 \\
EM12 & -1.10 & 85.2 & 90.6 & 92.9 & 73.7 & 78.6 & 83.3 & 86.6 & 84.2 \\
\hline
\end{tabular}

The results were repeated by size. EM9 is applied to the greatest degree (over 91\%) in both small and medium-sized businesses, while EM1 continues to be the least frequent practice in small firms and EM8 in those of medium size.

The column of totals shows that in Canary Island SMEs the degree of implantation of environmental policies is fairly optimal. The percentages exceed values of $70 \%$ in almost all the strategies of EM analyzed, except EM1 and EM8 (percentage of application lower than $50 \%$ ).

\subsection{Cluster analysis and ANOVA}

The result of the two-phase cluster analysis (Hair et al. 1998) allows three segments of firms to be identified, which are characterized by their having a high (cluster 1), medium (cluster 2) and low (cluster 3 ) level of implantation and implication with EM (Table 5).

The ANOVA confirmed that significant differences exist among the three clusters delimited (confidence level of 99\%). Likewise, confirmation is made of the correct association of the SMEs to the segment or cluster to which they belong on the basis of all the classification variables (rasch_EM, Rec, Inv and size). The only exception is the "sector" variable, indicating the type of sector to which the SME belongs, and is independent of the segment or cluster with which they are identified.

Having confirmed the heterogeneous character of the three segments of Canary Island SMEs, the next step is to analyze their differentiating characteristics to delimit the profile of each, thereby achieving our fourth objective.

Group 1, "Proactive" ("high level of implantation of EM") comprises 164 firms (39.8\% of the total). In all the classification variables employed, the SMEs in this group present the highest values, for both the measurement of EM (rasch_EM) and for resources employed (rec) and investment level (inv). It is the group with the greatest proportion of medium-sized enterprises $(34.1 \%)$. The main sector in this group is industry $(34.1 \%)$. 
Table 5. Profiles of the variables defining the clusters

\begin{tabular}{|c|c|c|c|c|}
\hline Variable & Item & $\begin{array}{c}\text { Cluster } 1 \\
40 \%\end{array}$ & $\begin{array}{c}\text { Cluster } 2 \\
46 \%\end{array}$ & $\begin{array}{c}\text { Cluster } 3 \\
15 \%\end{array}$ \\
\hline rasch_EM & ${ }^{\mathrm{a}} \mathrm{EM}$ & 3.6 & 0.5 & -1.5 \\
\hline rec & $\begin{array}{l}\text { Volume of economic, human and technical } \\
\text { resources currently assigned to environmental } \\
\text { protection }\end{array}$ & 3.5 & 2.9 & 2.4 \\
\hline inv & $\begin{array}{l}\text { protection with regard to the total volume of assets } \\
\text { of the company }\end{array}$ & 3.4 & 2.9 & 2.3 \\
\hline \multirow{2}{*}{ Size } & Small & $66 \%$ & $77 \%$ & $80 \%$ \\
\hline & Medium & $34 \%$ & $23 \%$ & $20 \%$ \\
\hline \multirow{5}{*}{ sector } & Industrial & $34 \%$ & $34 \%$ & $25 \%$ \\
\hline & Construction & $18 \%$ & $24 \%$ & $15 \%$ \\
\hline & Hospitality & $13 \%$ & $7 \%$ & $10 \%$ \\
\hline & Transport & $9 \%$ & $9 \%$ & $12 \%$ \\
\hline & Others & $25 \%$ & $26 \%$ & $38 \%$ \\
\hline \multirow{5}{*}{ certification } & Possesses or is the process of gaining: & & & \\
\hline & ISO 14001 Certificate & $54 \%$ & $20 \%$ & $12 \%$ \\
\hline & EMAS & $2 \%$ & - & $2 \%$ \\
\hline & Other accreditation of environmental quality & $10 \%$ & $9 \%$ & $10 \%$ \\
\hline & Does not possess any accreditation & $34 \%$ & $71 \%$ & $77 \%$ \\
\hline
\end{tabular}

Nores: (a) Variable resulting from the transformation of the EM items with RMT; (b) Variables measured with a Likert scale $(1=$ none $5=$ much $)$.

The majority in this group (66.5\%) possess some type of accreditation of environmental quality, with 56.1\% possessing EM systems certified with ISO 14001 (54.3\%) or EMAS $(1.8 \%)$.

Group 2, "Compliance" ("average level of implantation of EM") is the largest (188 SMEs, $45.6 \%$ of the sample). It is characterized by the EM measurement variables of resources employed and of the amount of environmental investment, which reach average values with regard to the three groups of SMEs delimited. This group increases the proportion of small SMEs (76.6\%) compared to group 1 whereas its distribution by sectors proves to be very similar. The level of accreditation is medium-low, with only $29.3 \%$ of SMEs possessing some type of certification, those that do (20.4\%) hold an ISO 14001, no firm certified with EMAS is present.

Group 3, "Reactive" ("low level of implantation of EM") is the smallest group (60 SMEs, $14.6 \%$ of the total). It presents lower values in the measurements of the grouping variables, which suggests that it comprises SMEs with similarly low implication in EM practices. $80 \%$ of firms are small (under 50 employees) and belong in their majority to the distribution and retail sectors. Only $13.4 \%$ of these SMEs possess an ISO 14001 $(11.7 \%)$ or EMAS $(1.7 \%)$ certificate, while $76.7 \%$ state they do not possess nor are they in the process of possessing any other type of environmental accreditation. 


\section{Discussion}

Findings obtained make a relevant contribution in line with the gaps highlighted by previous literature.

Firstly, there is the progress in measuring constructs in Strategic Management and the NRBV, according to Barney et al. $(2001,2011)$. The application of RMT stands out in particular in the measurement of intangible resources. We confirm the overall validity and reliability of the measures obtained for the level of implantation of EM in Canary Island SMEs (first objective). It has also established a premise of the quality guarantee for subsequent results (Aragón, Iturrioz 2016), thus reinforcing its applicability in similar territories.

The second objective consisted of determining the importance of the policies representing the EM of SMEs. The practices most widely applied are the correct management of waste and dangerous substances and the training and motivation of personnel to achieve the environmental objectives. The least frequent strategy is the implantation of a formalized EM system, which involves a permanent allocation of resources that SMEs do not usually have available, as shown in the literature review. In this ranking, there are no substantial differences between medium-sized and small firms, while for sectors, consistent with Banerjee (2002), relatively less regulated services display lower levels of corporate environmentalism (transport, distribution and retail).

The third objective confirms the existence of three levels of environmental commitment clearly differentiated in Canary Island SMEs, described as: "Reactive" - cluster 3 (lowest commitment); strategic attitude of cluster 2 would be defined as 'Compliance' (prevention of pollution), while cluster 1 "Proactive" (highest level of environmental commitment), whose firms employ the greatest volume of resources in EM. While "Compliance" responds to external pressures (stakeholders), "Proactive" responds to internal motivations and EM is integrated into its strategic planning and designed on the basis of resources and capacities (López-Gamero, Molina-Azorín 2016). According to NRBV, the delimitation of this typology is crucial to identify the resources and dynamic capabilities that can transform environmental challenges into sources of competitive advantage (Hart, Dowell 2011).

The smallest firms (mainly present in clusters 2 and 3) have the lowest levels of EM, in accordance with Brammer et al. (2012).

Figure 1 summarizes the strategic configuration of EM in the sample.

This study covers a wide spectrum of sectors, however the results indicate that differences in sectoral composition of delimited groups do not prove significant in their approach to EM. Nevertheless, a predominance of medium-sized enterprises exists as opposed to small firms in the 'Proactive' cluster. In line with the literature, this indicates the incidence of firm size on level of environmental responsibility (Nybakk, Panwar 2015) and implies a significant contribution to the gap in previous research about considering the heterogeneity of small and medium-sized firms (Brammer et al. 2012). 


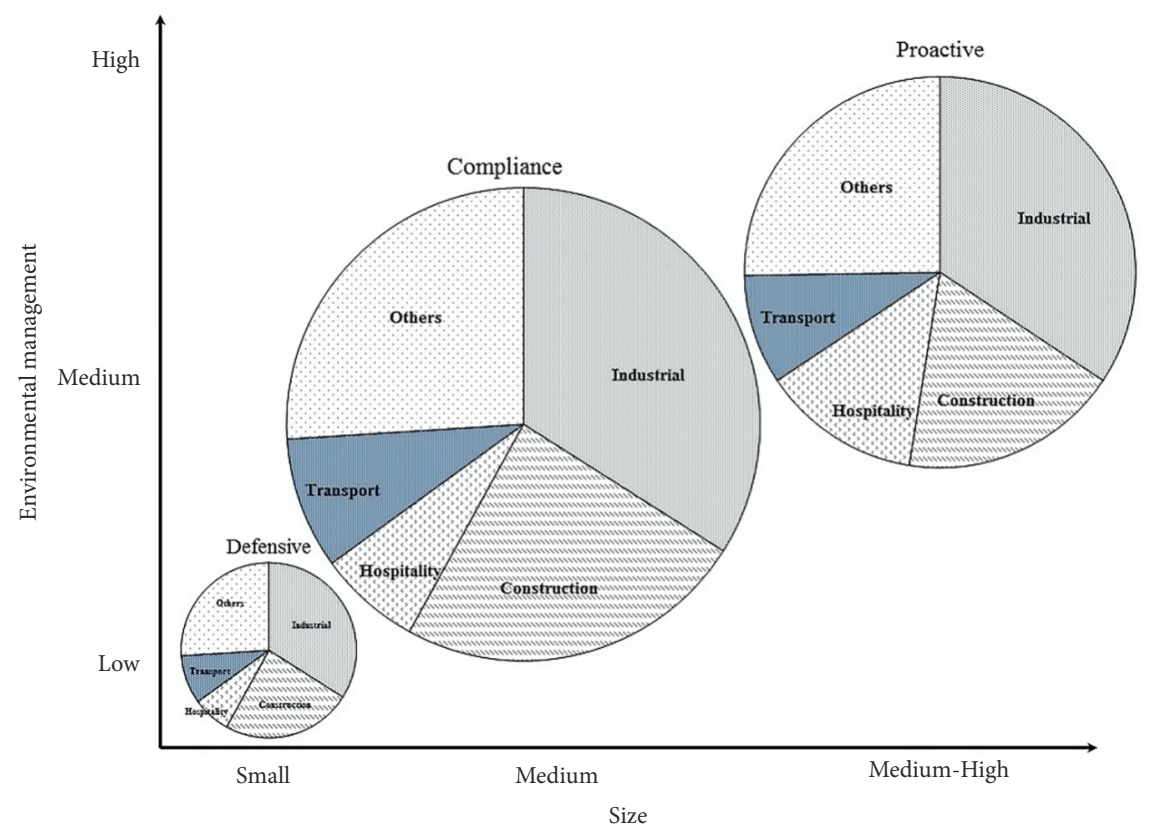

Fig. 1. Strategic EM typologies

\section{Conclusions}

In addition to the necessary analysis of SMEs in the particular context of an insular peripheral territory, this paper contributes to prior research findings in several ways. Firstly, progress has been made in measuring unobservable constructs in Strategic Management and the NRBV, particularly intangible resources and capabilities. "EM" in Canary Island SMEs has been validated and RMT methodology also guarantees the applicability of this construct for the analysis of other similar territories. This empirical application reinforces the prior scarce use of RBT in research into CRS in SMEs.

Furthermore, it has been delimited SME's internal dynamics to develop value-creating responsible strategies. We confirm that SMEs in this OER have a satisfactory level of environmental commitment, with practices of prevention and control of impact predominating. Specifically, most widely applied practices are the management of waste and dangerous substances and the training and motivation of personnel. These two aspects do not demand excessive resources and guarantee SMEs' compliance with the legislation in force as regards waste and discharges. However, SMEs still have much room for improvement in integrating EM in strategic planning by incorporating standardized environmental systems in line with the limitations of the context of the OERs, where costs of distance and insularity limit even further the availability of necessary resources for SMEs to implant such rigorous standards.

According to above, another important contribution to NRBV is the identification of best positioned firms to develop that "green" dynamic capabilities with the potential to generate competitive advantage. A typology of environmental strategies which charac- 
terize SMEs' behavior in this OER have been identified as "Reactive", which groups together firms that elude to a maximum extent their environmental responsibility, attempting to delay the incorporation of these aspects into their management criteria and dedicating the lowest investment of resources; "Compliance", focused on the prevention of environmental impact; and "Proactive" comprises those firms who develop much further their EM with the perspective of the opportunity of attaining competitive advantages, thereby adopting a position of environmental leadership.

From both scientific and managerial perspectives, the analysis of this proactive group is crucial to advance the knowledge of the resources and capabilities that can generate a sustainable competitive advantage. According to that, by analyzing different productive sectors (industry, construction, hospitality, transport, distribution and retail, where the services sector accounts for $46 \%$ of the sample, conveniently reflecting the business fabric of insular OERs), we could verify that, in this sample of SMEs, there are no differences in the environmental strategic position due to sectoral specificities. However, firms' size is determinant in strategic management of environment, since "Proactive" firms are mainly medium-sized. The smallest firms' EM is oriented towards operational and not strategic elements due to the perception of small firms that such management does not provide them with opportunities to generate competitive advantages. These findings permitted us to contribute to the gaps highlighted by previous literature with respect to explore the heterogeneity of EM between small and medium-sized firms, and the necessary comparison between business sectors.

In summary, this paper contributes from the point of view of NRBV and in both political and managerial planning processes in OERs. Future research should advance the delimitation of social-environmental capabilities that have potential to generate competitive advantages by comparing other OER and to advancing from cross sectional to longitudinal analysis.

\section{References}

Aguinis, H.; Glavas, A. 2012. What we know and don't know about corporate social responsibility: a review and research agenda, Journal of Management 38(4): 932-968.

https://doi.org/10.1177/0149206311436079

Aragón, C.; Iturrioz, C. 2016. Responsible family ownership in small- and medium-sized family enterprises: an exploratory study, Business Ethics: A European Review 25(1): 75-93.

https://doi.org/10.1111/beer.12078

Aragón-Correa, J. A. 1998. Strategic proactivity and firm approach to the natural environment, Academy of Management Journal 41(5): 556-567. https://doi.org/10.2307/256942

Aragón-Correa, J.; Hurtado-Torres, N.; Sharma, S.; García-Morales, V. 2008. Environmental strategy and performance in small firms: a resource-based perspective, Journal of Environmental Management 86(1): 88-103. https://doi.org/10.1016/j.jenvman.2006.11.022

Armas-Cruz, Y. 2011. Determinants of environmental management and implications in firms' economic performance, Journal of Environmental Planning and Management 54(8): 1077-1106. https://doi.org/10.1080/09640568.2010.549401

Baldacchino, G. 2007. A world of islands: an island studies reader. Charlottetown: Island Studies Press. 
Baldacchino, G. 2008. Studying islands: on whose terms? Some epistemological and methodological challenges to the pursuit of island studies, Island Studies Journal 3(1): 37-56.

Banerjee, S. B. 2002. Corporate environmentalism. The construct and its measurement, Journal of Business Research 55: 177-191. https://doi.org/10.1016/S0148-2963(00)00135-1

Barney, J. B. 1991. Firm resources and sustained competitive advantage, Journal of Management 17(1): 99-120. https://doi.org/10.1177/014920639101700108

Barney, J. B. 2001a. Is the resource-based 'view' a useful perspective for strategic management research? 'Yes', Academy of Management Review 26: 41-56. http://www.jstor.org/stable/259393

Barney, J. B. 2001b. Resource-based theories of competitive advantage: a ten year retrospective on resource-based view, Journal of Management 27: 643-650.

https://doi.org/10.1177/014920630102700602

Barney, J. B.; Ketchen, D. J.; Wright, M. 2011. The future of Resource-Based Theory: revitalization or decline?, Journal of Management 37(5): 1299-1315. https://doi.org/10.1177/0149206310391805

Barney, J. B.; Wright, M.; Ketchen, D. 2001. The resource-based view of the firm: ten years after 1991, Journal of Management 27: 625-641. https://doi.org/10.1177/014920630102700601

Benito-Hernández, S.; Platero-Jaime, M.; Esteban-Sánchez, P. 2016. The influence of cooperative relations of small businesses on environmental protection intensity, Business Ethics: A European Review 25(4): 416-439. https://doi.org/10.1111/beer.12126

Blundel, R.; Monaghan, A.; Thomas, C. 2013. SMEs and environmental responsibility: a policy perspective, Business Ethics: A European Review 22(3): 246-262.

https://doi.org/10.1111/beer.12020

Bos-Brouwers, H. 2010. Corporate sustainability and innovation in SMEs: evidence of themes and activities in practices, Business Strategy and the Environment 19(7): 417-435.

https://doi.org/10.1002/bse.652

Boyd, B. K.; Gove, S.; Hitt, M. A. 2005. Construct measurement in strategic management research: illusion or reality?, Strategic Management Journal 26: 239-257.

https://doi.org/10.1002/smj.444

Brammer, S.; Hoejmose, S.; Marchant, K. 2012. Environmental management in SMEs in the UK: practices, pressures and perceived benefits, Business Strategy and the Environment 21(7): 423-434. https://doi.org/10.1002/bse.717

Calado, H.; Vergílio, M.; Fonseca, C.; Gil, A.; Moniz, F.; Ferreira, S.; Moreira, M.; Bragagnolo, C.; Silva, C.; Pereira, M. 2014. Developing a planning and management system for protected areas on Small Islands (The Azores Archipelago, Portugal): the SMARTPARKS project, Journal of Integrated Coastal Zone Management 14(2): 335-344. https://doi.org/10.5894/rgci496

Carroll, R. J.; Primo, D. M.; Richter, B. K. 2016. Using Item Response Theory to improve measurement in strategic management: an application to corporate social responsibility, Strategic Management Journal 37: 66-85. https://doi.org/10.1002/smj.2463

Christmann, P. 2000. Effects of 'best practices' of environmental management on cost advantage: the role of complementary assets, Academy of Management Journal 43(4): 663-680.

https://doi.org/10.2307/1556360

Coase, R. H. 1937. The nature of the firm, Economica N.S. 4: 386-405.

https://doi.org/10.1111/j.1468-0335.1937.tb00002.x

Curkovic, S.; Sroufe, R. 2016. A literature review and taxonomy of environmentally responsible manufacturing, American Journal of Industrial and Business Management 6: 323-346.

https://doi.org/10.4236/ajibm.2016.63030

Deng, S. L.; Ryan, C.; Moutinho, L. 1992. Canadians hoteliers and their attitudes towards environmental issues, International Journal of Hospitality Management 11(3): 225-237.

https://doi.org/10.1016/0278-4319(92)90020-V 
Engelhard, G. 2013. Invariant measurement: summary and discussion, Chapter 12 in G. Engelhard (Ed.). Invariant measurement. Using Rasch Models in the social, behavioral, and health sciences. New York and London: Routledge, 247-256.

Fassin, Y. 2008. SMEs and the fallacy of formalising CSR, Business Ethics: A European Review 17(4): 364-378. https://doi.org/10.1111/j.1467-8608.2008.00540.x

Frynas, J. G.; Stephens, S. 2015. Political corporate social responsibility: reviewing theories and setting new agendas, International Journal of Management Reviews 17: 483-509.

https://doi.org/10.1111/ijmr.12049

Frynas, J. G.; Yamahaki, C. 2016. Corporate social responsibility: review and roadmap of theoretical perspectives, Business Ethics: A European Review 25(3): 258-285.

Gadenne, D.; Kennedy, J.; McKeiver, C. 2009. An empirical study of environmental awareness and practices in SMEs, Journal of Business Ethics 84(1): 45-63.

https://doi.org/10.1007/s10551-008-9672-9

Gil, A.; Fonseca, C.; Lobo, A.; Calado, H. 2012. Linking GMES space component to the development of land policies in outermost regions - the Azores (Portugal) case-study, European Journal of Remote Sensing 45: 263-281. https://doi.org/10.5721/EuJRS20124524

Godfrey, P. C.; Hill, Ch. W. 1995. The problem of unobservables in strategic management research, Strategic Management Journal 16: 519-533. https://doi.org/10.1002/smj.4250160703

González-Benito, J.; González-Benito, O. 2005. Environmental proactivity and business performance: an empirical analysis, Omega 33: 1-15. https://doi.org/10.1016/j.omega.2004.03.002

Graafland, J.; Van de Ven, B.; Stoffele, N. 2003. Strategies and instruments for organising CSR by small and large businesses in the Netherlands, Journal of Business Ethics 47(1): 45-60.

https://doi.org/10.1023/A:1026240912016

Gupta, M. C.; Sharma, K. 1996. Environmental operations management: an opportunity for improvement, Production and Inventory Management Journal 37(3): 40-46.

Hair, J. F.; Anderson, R. E.; Tatham, R. L.; Black, W. C. 1998. Multivariate data analysis. Prentice Hall International, 439-564.

Hart, S. L. 1995. A natural Resource-Based View of the firm, Academy of Management Review 20(4): 986-1014. http://www.jstor.org/stable/258963

Hart, S. L.; Ahuja, G. 1996. Does it pay to be green? An empirical examination of the relationship between emission reduction and firm performance, Business Strategy and the Environment 5(1): 30-37. https://doi.org/10.1002/(SICI)1099-0836(199603)5:1<30::AID-BSE38>3.0.CO;2-Q

Hart, S. L.; Dowell, G. 2011. A natural Resource-Based View of the firm: fifteen years after, Journal of Management 37(5): 1464-1479. https://doi.org/10.1177/0149206310390219

Henriques, I.; Sadorsky, P. 1996. The determinants of environmentally responsive firm: an empirical approach, Journal of Environmental Economics and Management 30: 381-395.

https://doi.org/10.1006/jeem.1996.0026

Herrera-Madueño, J.; Larrán-Jorge, M.; Lechuga-Sancho, M. P.; Martínez-Martínez, D. 2015. The evolution of corporate social responsibility in small and medium enterprises literature as a research discipline, Revista Europea de Dirección y Economía de la Empresa 24: 117-128. https://doi.org/10.1016/j.redee.2014.06.001

Herrera Madueño, J.; Larrán-Jorge, M.; Martínez-Conesa, I.; Martínez-Martínez, D. 2016. Relationship between corporate social responsibility and competitive performance in Spanish SMEs: empirical evidence from a stakeholders' perspective, BRQ Business Research Quarterly 19(1): 55-72. https://doi.org/10.1016/j.brq.2015.06.002

Hofmann, K. H.; Theyel, G.; Wood, C. H. 2012. Identifying firm capabilities as drivers of environmental management and sustainability practices - evidence from small and medium-sized manufacturers, Business Strategy and the Environment 21: 530-545.

https://doi.org/10.1002/bse.739 
Hunt, C. B.; Auster, E. R. 1990. Proactive environmental management: avoiding the toxic trap, Sloan Management Review 31(2): 7-18.

Husillos, J.; Álvarez-Gil, M. J. 2008. A Stakeholder-Theory approach to environmental disclosures by small and medium enterprises (SMEs), Revista de Contabilidad 11(1): 125-156.

Jamali, D.; Zanhour, M.; Keshishian, T. 2009. Peculiar strengths and relational attributes of SMEs in the context of CSR, Journal of Business Ethics 87: 355-377.

https://doi.org/10.1007/s10551-008-9925-7

Jensen, M. C.; Meckling, W. H. 1976. Theory of the firm: managerial behavior, agency costs and ownership structure, Journal of Financial Economics 3(4): 305-360.

https://doi.org/10.1016/0304-405X(76)90026-X

Jong, P.; Paulraj, A.; Blome, C. 2014. The financial impact of ISO 14001 certification: top-line, bottom-line, or both?, Journal of Business Ethics 119: 131-149.

https://doi.org/10.1007/s10551-012-1604-z

Judge, W. Q.; Douglas, T. J. 1998. Performance implications of incorporating natural environmental issues into the strategic planning process: an empirical assessment, Journal of Management Studies 35(2): 241-262. https://doi.org/10.1111/1467-6486.00092

Kirk, D. 1995. Environmental management in hotels, International Journal of Contemporary Hospitality Management 7(6): 3-8. https://doi.org/10.1108/09596119510095325

Kirk, D. 1998. Attitudes to environmental management held by a group of hotel managers in Edinburgh, Hospitality Management 17: 33-47. https://doi.org/10.1016/S0278-4319(98)00005-X

Klassen, R. D.; Whybark, D. C. 1999. Environmental management in operations: the selection of environmental technologies, Decision Sciences 30(3): 601-631.

https://doi.org/10.1111/j.1540-5915.1999.tb00900.x

Kleiner, A. 1991. What does it mean to be green?, Harvard Business Review July-August: 38-47.

Larrán-Jorge, M.; Herrera-Madueño, J.; Martínez-Martínez, D.; Lechuga-Sancho, M. P. 2015. Competitiveness and environmental performance in Spanish small and medium enterprises: is there a direct link?, Journal of Cleaner Production 101: 26-37.

https://doi.org/10.1016/j.jclepro.2015.04.016

Lawrence, S. R.; Collins, E.; Pavlovich, K.; Arunachalam, M. 2006. Sustainability practices of SMEs: the case of NZ, Business Strategy and the Environment 15: 242-257.

https://doi.org/10.1002/bse.533

Lepoutre, J.; Heene, A. 2006. Investigating the impact of firm size on small business social responsibility: a critical review, Journal of Business Ethics 67(3): 257-273.

https://doi.org/10.1007/s10551-006-9183-5

Linacre, J. M. 2002. Optimizing rating scale category effectiveness, Journal of Applied Measurement 3(1): 85-106.

López-Gamero, M. D.; Pertusa-Ortega, E. M.; Molina-Azorín, J. F.; Tarí-Guilló, J. J.; PereiraMoliner, J. J. 2016. Organizational antecedents and competitive consequences of environmental proactivity in the hotel industry, Journal of Sustainable Tourism 24(7): 949-970.

https://doi.org/10.1080/09669582.2015.1101124

López-Gamero, M. D.; Molina-Azorín, J. F. 2016. Environmental management and firm competitiveness: the joint analysis of external and internal elements, Long Range Planning 49(6): 746-763. https://doi.org/10.1016/j.lrp.2015.12.002

López-Gamero, M. D.; Molina-Azorín, J. F.; Claver-Cortés, E. 2009. The whole relationship between environmental variables and firm performance: competitive advantage and firm resources as mediator variables, Journal of Environmental Management 90(10): 3110-3121.

https://doi.org/10.1016/j.jenvman.2009.05.007 
Martín-de Castro, G.; Amores-Salvadó, J.; Navas-López, J. E. 2016. Environmental management systems and firm performance: improving firm environmental policy through stakeholder engagement, Corporate Social Responsibility and Environmental Management 23: 243-256. https://doi.org/10.1002/csr.1377

McWilliams, A.; Siegel, D. S. 2011. Creating and capturing value: strategic corporate social responsibility, resource-based theory, and sustainable competitive advantage, Journal of Management 37(5): 1480-1495. https://doi.org/10.1177/0149206310385696

Mohd, N. J.; Rasi, R.; Ahmad, F. 2015. Review of enviropreneurial value chain (EVC) based on SCOR model and NRBV theory, Procedia - Social and Behavioral Sciences 172: 411-418. https://doi.org/10.1016/j.sbspro.2015.01.393

Moore, G.; Slack, R.; Gibbon, J. 2009. Criteria for responsible business practice in SMEs: an exploratory case of UK fair trade organizations, Journal of Business Ethics 89(2): 173-188. https://doi.org/10.1007/s10551-008-9992-9

Nybakk, E.; Panwar, R. 2015. Understanding instrumental motivations for social responsibility engagement in a micro-firm context, Business Ethics: A European Review 24(1): 18-33.

https://doi.org/10.1111/beer.12064

Oreja-Rodríguez, J. R.; Armas-Cruz, Y. 2012. Environmental performance in the hotel sector. The case of the western Canary Islands, Journal of Cleaner Production 29-30: 64-72.

https://doi.org/10.1016/j.jclepro.2012.02.012

Peattie, K.; Ringler, A. 1994. Management and the environment in the United Kingdom and Germany: a comparison, European Management Journal 12(2): 216-225.

https://doi.org/10.1016/0263-2373(94)90013-2

Porter, M. E. 1980. Competitive strategy: techniques for analyzing industries and competitors. New York: Free Press.

Porter, M. E.; Van der Linde, C. 1995. Green and competitive: ending the stalemate, Harvard Business Review 73(5): 120-134.

Pugh, J. 2016. The relational turn in island geographies: bringing together island, sea and ship relations and the case of the Landship, Social \& Cultural Geography 17(8): 1040-1059.

https://doi.org/10.1080/14649365.2016.1147064

Rasch, G. 1960. Probabilistic models for some intelligence and attainment tests. Chicago: University of Chicago Press (1980 expanded edition).

Revell, A.; Blackburn, R. 2007. The business case for sustainability? An examination of small firms in the UK's construction and restaurant sectors, Business Strategy and the Environment 16: 404-442. https://doi.org/10.1002/bse.499

Rodríguez-Fernández, M. 2016. Social responsibility and financial performance: the role of good corporate governance, Business Research Quarterly 19: 137-151.

https://doi.org/10.1016/j.brq.2015.08.001

Rueda-Manzanares, A.; Aragón-Correa, J. A.; Sharma, S. 2008. The influence of stakeholders on the environmental strategy of service firms: the moderating effects of complexity, uncertainty and munificence, British Journal of Management 19: 185-203.

https://doi.org/10.1111/j.1467-8551.2007.00538.x

Russo, M. V.; Fouts, P. A. 1997. A resource-based perspective on corporate environmental performance and profitability, Academy of Management Journal 40(3): 534-559.

https://doi.org/10.2307/257052

Sarstedt, M.; Diamantopoulos, A.; Salzberger, T.; Baumgartner, P. 2015. Selecting single items to measure doubly-concrete constructs: a cautionary tale, Journal of Business Research 69(8): 3159-3167. https://doi.org/10.1016/j.jbusres.2015.12.004

Sharma, S. 2000. Managerial interpretations and organizational context as predictors of corporate choice of environmental strategy, Academy of Management Journal 43(4): 681-697.

https://doi.org/10.2307/1556361 
Stratford, E.; Baldacchino, G.; McMahon, E.; Farbotko, C.; Harwood, A. 2011. Envisioning the archipelago, Island Studies Journal 6(2): 113-130.

Teece, D. 2007. Explicating dynamic capabilities: the nature and microfoundations of (sustainable) enterprise performance, Strategic Management Journal 28: 1319-1350.

https://doi.org/10.1002/smj.640

Tomomi, T. 2010. Environmental management strategy for small and medium-sized enterprises: why do SMBs practice environmental management?, Asian Business \& Management 9: 265-280. https://doi.org/10.1057/abm.2010.6

Torugsa, N.; O'Donohue, W.; Hecker, R. 2012. Capabilities, proactive CSR and financial performance in SMEs: empirical evidence from an Australian manufacturing industry sector, Journal of Business Ethics 109: 483-500. https://doi.org/10.1007/s10551-011-1141-1

Udayasankar, K. 2008. Corporate social responsibility and firm size, Journal of Business Ethics 83(2): 167-175. https://doi.org/10.1007/s10551-007-9609-8

Verbeke, A.; Bowen, F.; Sellers, M. 2006. Corporate environmental strategy: extending the Natural Resource-Based View of the firm, in Academy of Management Proceedings, Meeting Abstract, (Supplement), 1 August 2006, A1-A6. https://doi.org/10.5465/AMBPP.2006.27176644

Wang, W. C. 2010. Recent developments in Rasch measurement [online], [cited 20 October 2016]. Hong Kong: The Hong Kong Institute of Education. Available from Internet: http://repository.lib.eduhk.hk/jspui/handle/2260.2/10260

Wight, P. 1994. The greening of the hospitality industry: economic and environmental good sense, Chapter 69 in A. V. Seaton, C. L. Jenkins, R. C. Wood, P. U. C. Pieke, M. M. Bennet, L. R. McLellan, R. Smith (Eds.). Tourism: the state of the art. Chichester: John Willey, 665-674. Williamson, O. E. 1985. The economic institutions of capitalism. New York: Free Press.

Wolters, T.; James, P.; Bouman, M. 1997. Stepping-stones for integrated chain management in the firms, Business Strategy and the Environment 6(3): 121-132.

https://doi.org/10.1002/(SICI)1099-0836(199707)6:3<121::AID-BSE107>3.0.CO;2-C

Wong, C. W. Y.; Lai, K. H.; Lun, Y. H. V.; Cheng, T. C. E. 2015. Environmental management, in C. W. Y. Wong, K. H. Lai, Y. H. V. Lun, T. C. E. Cheng (Eds.). Environmental management: the supply chain perspective. Springer, 1-27.

http://dx.doi.org/10.1007/978-3-319-23681-0

Yaiza ARMAS-CRUZ is PhD in Business Management and Professor in the Department of Business Management and Economic History at the University of La Laguna (Spain). Her research is primarily in the area of corporate environmental strategies and management. She has published several research articles in refereed journals of Business and Management subject categories.

Esperanza GIL-SOTO is $\mathrm{PhD}$ in Business Administration and Professor in the Department of Business and Economic History at the Universidad de La Laguna (Spain). Some of their main lines of research are focused on entrepreneurial orientation analysis and the evaluation of entrepreneurship education. She has also published in other fields as management information systems and environmental management.

Juan Ramón OREJA-RODRÍGUEZ is Full Professor of Strategy Management at Universidad de La Laguna (Spain). His research focuses on the cognitive approach to management: Competitive Analysis, environmental scanning, uncertainty and risk in decision making, strategy formulation; methodology of the objective measurement (Rasch Measurement Theory). He has published the results of his research in books, book chapters, congress proceedings and articles in refereed journals. 